\title{
Abnormalities of the placenta
}

\author{
Alexander Heazell \\ From Stillbirth Summit 2011 \\ Minneapolis, MN, USA. 6-8 October 2011
}

Normal placental structure and function is essential for a healthy pregnancy; the placenta is responsible for nutrient and oxygen transport, removal of waste products, protection from infection, modulation of the maternal immune system and hormone production to maintain pregnancy. The human placenta is structurally adapted to fulfil this role as it is haemomonochorial, minimising the distance between maternal and fetal circulations to maximise exchange. Disorders of the placenta including: FGR, pre-eclampsia, placental abruption and abnormal (velamentous) cord insertion are associated with over $50 \%$ of stillbirths and are frequently cited as the primary cause of death [1-3].

Abnormal placental structure and function significantly increases the risk of stillbirth. Levels of pregnancy associated plasma protein A (PAPP-A) in the lowest $5 \%$ and alpha fetoprotein (AFP) in the highest $5 \%$ increase the risk of stillbirth by 50 -fold and 2.8 -fold respectively $[4,5]$. In women at high-risk of pregnancy complications, abnormal placental structure and/or blood flow seen by ultrasound scan at 19-23 weeks preceded 15 out of 22 stillbirths [6]. There are few studies of microscopic placental structure in stillbirth. However, microscopic structure and cell turnover of the villous trophoblast are disrupted in FGR and pre-eclampsia [7-9]. Evidence from genetic analyses demonstrated that gene imprinting in the placenta is altered in pregnancy loss [10]. The importance of placenta genetics and epigenetics is supported by the observation of increased stillbirth and pregnancy loss in confined placental mosaicism where genetic abnormalities are only present in the placenta [11].

Due to its central role in determining pregnancy outcome, detailed examination of the placenta can give useful information about the cause of stillbirth and is recommended by the Royal College of Obstetricians and Gynaecologists (RCOG), American College of Obstetricians and Gynecologists (ACOG) and Perinatal Society of

\footnotetext{
Correspondence: Alexander.Heazell@manchester.ac.uk
} University of Manchester, UK
Australia and New Zealand (PSANZ) [12,13]. Examination of the placenta reduces the proportion of unexplained stillbirths [14]. Consequently, examination of the placenta is one of the most common investigations undertaken after a stillbirth and is one of the most valuable $[2,15]$.

Despite the value of placental examination to identify conditions associated with stillbirth including: fetal thrombotic vasculopathy, chronic intervillositis, villitis, chorioamnionitis, funisitis, infarction, massive perivillous fibrin deposition, villous dysmaturity (increased syncytial knot formation), villous immaturity and cord lesions further research is needed to increase the understanding of placental pathology in stillbirth. This is reflected in the research priorities for high-income countries synthesised by an international panel of experts which mention need for repositories of well-phenotyped samples from stillbirths and from well-matched controls and the need to understand the pathophysiological pathways in common conditions associated with stillbirth including: diabetes, cigarette smoking and maternal obesity [16].

An important goal of translational medicine is to use the increased understanding of placental dysfunction to develop improved tests of pregnancy wellbeing. For example, factors derived from the placenta, such as human placental lactogen or placental growth factor may provide novel means to identify pregnancies at highest risk of stillbirth [17]. Discovery-based technologies such as proteomics or metabolomics offer the opportunity to analyse biofluids and tissue in hypothesis-generating studies to provide a more holistic understanding of fetal and placental dysfunction. Better understanding of the role of the placenta in stillbirth offers the opportunity to develop strategies to identify placental dysfunction in pregnancies, in order that intervention may be targeted to prevent stillbirth.

Published: 28 August 2012 


\section{References}

1. Gardosi J, Kady SM, McGeown P, Francis A, Tonks A: Classification of stillbirth by relevant condition at death (ReCoDe): population based cohort study. British Medical Journal 2005, 331:1113-1117.

2. Confidential Enquiry into Maternal and Child Health: Perinatal Mortality 2008: England, Wales and Northern Ireland. London: Centre for Enquiries into Maternal and Child Health; 2010.

3. Vergani P, Cozzolino S, Pozzi E, Cuttin MS, Greco M, Ornaghi S, Lucchini V: Identifying the causes of stillbirth: a comparison of four classification systems. Am J Obstet Gynecol 2008, 199:319.e1-4.

4. Smith GC, Crossley JA, Aitken DA, Pell JP, Cameron AD, Connor JM, Dobbie R: First-trimester placentation and the risk of antepartum stillbirth. JAMA 2004, 292:2249-2254.

5. Smith GC, Shah I, Crossley JA, Aitken DA, Pell JP, Nelson SM, Cameron AD, Connor MJ, Dobbie R: Pregnancy-associated plasma protein A and alphafetoprotein and prediction of adverse perinatal outcome. Obstet Gynecol 2006, 107:161-166

6. Toal M, Chan C, Fallah S, Alkazaleh F, Chaddha V, Windrim RC, Kingdom JC: Usefulness of a placental profile in high-risk pregnancies. Am J Obstet Gynecol 2007, 196:363.e1-7.

7. Leung DN, Smith SC, To KF, Sahota DS, Baker PN: Increased placental apoptosis in pregnancies complicated by preeclampsia. Am J Obstet Gynecol 2001, 184:1249-1250.

8. Heazell AE, Moll SJ, Jones CJ, Baker PN, Crocker IP: Formation of syncytial knots is increased by hyperoxia, hypoxia and reactive oxygen species. Placenta 2007, 28:S33-S40.

9. Heazell AE, Sharp AN, Baker PN, Crocker IP: Intra-uterine growth restriction is associated with increased apoptosis and altered expression of proteins in the p53 pathway in villous trophoblast. Apoptosis 2011, 16:135-144.

10. Doria S, Sousa M, Fernandes S, Ramalho C, Brandao O, Matias A, Barros A, Carvalho F: Gene expression pattern of IGF2, PHLDA2, PEG10 and CDKN1C imprinted genes in spontaneous miscarriages or fetal deaths. Epigenetics 2010, 5:444-450.

11. Goodfellow LR, Batra G, Hall V, McHale E, Heazell AE: A case of confined placental mosaicism with double trisomy associated with stillbirth. Placenta 2011, 32:699-703.

12. Royal College of Obstetricians and Gynaecologists: Green-Top Guideline 55 - Late Intrauterine Fetal Death and Stillbirth. London: Royal College of Obstetricians and Gynaecologists; 2010.

13. American College of Obstetricians and Gynecologists: ACOG Practice Bulletin No. 102: management of stillbirth. Obstet Gynecol 2009, 113:748-761.

14. Heazell $A E$, Martindale EA: Can post-mortem examination of the placenta help determine the cause of stillbirth? Journal of Obstetrics and Gynaecology 2009, 29:225-228.

15. Heazell AE, Byrd LM, Cockerill R, Whitworth MK: Investigations following stillbirth - which tests are most valuable? Arch Dis Child 2011, 96:Fa135.

16. Flenady V, Middleton P, Smith GC, Duke W, Erwich JJ, Khong TY, Neilson J, Ezzati M, Koopmans L, Ellwood D, Fretts R, Froen JF: Stillbirths: the way forward in high-income countries. Lancet 2011, 377:1703-1717.

17. Benton SJ, Hu Y, Xie F, Kupfer K, Lee SW, Magee LA, von Dadelszen P: Can placental growth factor in maternal circulation identify fetuses with placental intrauterine growth restriction? Am J Obstet Gynecol 2012, 206(2):163.e1-7.

\section{Submit your next manuscript to BioMed Central and take full advantage of:}

- Convenient online submission

- Thorough peer review

- No space constraints or color figure charges

- Immediate publication on acceptance

- Inclusion in PubMed, CAS, Scopus and Google Scholar

- Research which is freely available for redistribution

Submit your manuscript at www.biomedcentral.com/submit
Ciomed Central 